\title{
Article
}

\section{Welding of DOCOL 1200M using micro-jet cooling}

\author{
Abilio Silva ${ }^{1}$, Bożena Szczucka-Lasota ${ }^{2}$, Tomasz Węgrzynn ${ }^{2, *}$ and Adam Jurek ${ }^{3}$ \\ 1 University da Beira Interior, Portugal \\ Prof. Abilio Silva; abilio@ubi.pt \\ 2 Silesian University of Technology, Poland \\ Prof. Bożena Szczucka-Lasota; bozena.szczucka-lasota@polsl.pl \\ 3 Novar Sp. z o. o. Gliwice, Poland \\ * Correspondence: Prof. Tomasz Węgrzyn; Tomasz.Wegrzyn@polsl.pl \\ Received: 02.12.2019; Accepted: 24.01.2020
}

\begin{abstract}
In welding elements of the supporting structure of the means of transport, attention is paid to the high strength and good plastic properties of the welded joint. In the construction of transport means, DOCOL $1200 \mathrm{M}$ steel from the AHSS group is increasingly used due to their high tensile strength of steel at the level of $1200 \mathrm{MPa}$. The welds have much lower strength than the native material. In this paper, it was decided to check the weldability of DOCOL $1200 \mathrm{M}$ steel with the use of micro-jet cooling. A positive effect of micro-jet cooling on the mechanical properties of joints made on DOCOL 1200M steel was observed. A positive effect of micro-jet cooling on the mechanical properties of welded joints made of DOCOL 1200M steel has been observed.
\end{abstract}

Keywords: civil engineering; means of transport; AHSS steel; micro-jet cooling

\section{Introduction}

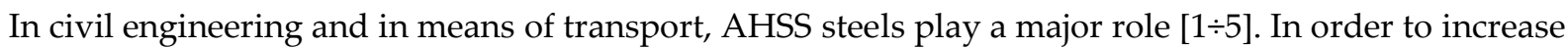
the usability of the elements of the vehicle supporting structure, it is aimed to increase their strength while maintaining the weight of the vehicle. The use of new materials, such as AHSS steels, entails technological changes associated with joining these elements. First of all, classic welding methods do not give the desired results in the form of obtaining durable and at the same time high-strength welded joints, whose tensile strength would be close to the values obtained for the native material. The analyzed structural elements made of AHSS steel have a strength of up to $1200 \mathrm{MPa}$, which is about $40 \%$ higher strength than the strength of welds obtained in the MAG process. It was decided for the first time to check whether the newly developed technology using micro-jet cooling is suitable for welding DOCOL 1200M steel and will affect the usable quality of welded joints and, above all, improve the tensile strength of the welds obtained $[6,7]$. This article aims to present selected test results and their analysis leading to the selection of welding parameters of the newly developed technology for joining thin-walled structure of mobile platform elements made of AHSS (Advanced High-Strength Steel).

The presented technology uses micro-jet cooling applied immediately after the welding process. This type of cooling has so far been used during the welding of unalloyed structural steels and aluminum alloys from the 1xxx, 5xxx and 6xxxx groups. Welding with micro-jet cooling of these materials gave positive results [6], however, the cooling parameters differed depending on the type of welded materials. When welding unalloyed steels, it was possible to achieve a significant increase in fine ferrite content in the weld, which translates into high impact strength of the joint at reduced temperature. In welding aluminum alloys, it was possible to fragment the weld structure, which allowed to obtain better mechanical properties of the joints. So far, no attempts have been made to use the process of welding with micro-jet cooling for joining steel of the AHSS group [7].

\section{Materials and methods}

High-strength DOCOL 1200M steels are increasingly used in civil engineering and transport due to their high tensile strength up to $1200 \mathrm{MPa}$. The strength of a weld made using the MAG method is much lower - at $700 \mathrm{MPa}[8,9]$. Relative joint elongation is at the level of $5 \%[10,11]$. When welding DOCOL $1200 \mathrm{M}$ steel, it is recommended to limit the heat input during welding to $0.5 \mathrm{~kJ} / \mathrm{mm}[12,13]$. In order to 
improve the weldability of steel, it is proposed to introduce cooling that promotes martensitic transformation [14]. Table I presents the mechanical properties of DOCOL 1200M steel.

Table I. Mechanical properties of DOCOL 1200M AHSS steel [15]

\begin{tabular}{|c|c|c|c|c|c|c|}
\hline \multirow[t]{2}{*}{ Steel grade } & \multicolumn{2}{|c|}{$\begin{array}{l}\text { Yield point } \\
\text { Rel }[\mathrm{MPa}]\end{array}$} & \multirow{2}{*}{$\begin{array}{c}\text { Yield point after } \\
\text { quenching and } \\
\text { tempering } \\
\text { min }\end{array}$} & \multicolumn{2}{|c|}{$\begin{array}{c}\text { Tensile strength } \\
R_{\mathrm{m}}[\mathrm{MPa}]\end{array}$} & \multirow{2}{*}{$\begin{array}{c}\text { Elongation } \\
\operatorname{R}_{80} \% \\
\text { min } \\
\end{array}$} \\
\hline & $\min$ & $\max$ & & $\min$ & $\max$ & \\
\hline DOCOL $1200 \mathrm{M}$ & 950 & - & 1150 & 1200 & 1400 & 5 \\
\hline
\end{tabular}

Steels from the AHSS group are considered difficult to weld because the heat affected zone is prone to cracks. This is the effect of the dominant martensitic structure of steel [10 $\div 12]$. Table II presents the chemical composition of DOCOL1200M steel used to build means of transport.

For the welding of DOCOL 1200M steel, UNION X90 electrode wire was selected (EN ISO 16834-A G 896 M21 Mn4Ni2CrMo) with the following chemical composition (Table III). The chemical composition of DOCOL $1200 \mathrm{M}$ wire and steel was similar.

Table II. Chemical composition of DOCOL 1200M steel [14]

\begin{tabular}{ccccccccc}
\hline Steel grade & $\mathbf{C} \%$ & $\mathbf{S i} \%$ & $\mathbf{M n} \%$ & $\mathbf{P} \%$ & $\mathbf{S} \%$ & $\mathbf{A l} \%$ & $\mathbf{N b} \%$ & $\mathbf{T i} \%$ \\
\hline DOCOL 1200M & 0.11 & 0.20 & 1.70 & 0.010 & 0.002 & 0.040 & 0.015 & 0.025 \\
\hline
\end{tabular}

Table III. Chemical composition of fillet material UNION X90 [14]

\begin{tabular}{ccccccccc}
\hline & $\mathbf{C} \%$ & $\mathbf{S i} \%$ & $\mathbf{M n} \%$ & $\mathbf{P} \%$ & $\mathbf{C r} \%$ & $\mathbf{M o} \%$ & $\mathbf{N i} \%$ & $\mathbf{T i} \%$ \\
\hline UNION X90 & 0.1 & 0.8 & 1.8 & 0.010 & 0.35 & 0.6 & 2.3 & 0.005 \\
\hline
\end{tabular}

The joined material was made of non-chamfered DOCOL 1200M steel sheets with a thickness of $2 \mathrm{~mm}$. The welding parameters were as follows: the diameter of the electrode wire was $1 \mathrm{~mm}$, arc voltage $19 \mathrm{~V}$, welding current $115 \mathrm{~A}$, welding speed $360 \mathrm{~mm} / \mathrm{min}$, weld with a single-pass character. According to literature data, $82 \% \mathrm{Ar}+18 \% \mathrm{CO}_{2}$ was selected from the shield mixtures for the MAG process [15]. The selected shielding gas gave the best results when welding steel from the AHSS group (no cracks in the joint and proper weld mechanical properties). Immediately after welding, micro-jet cooling (Fig. 1) was used with helium or argon with the following parameters (for both tested gases):

- micro-jet diameter: $60 \mu \mathrm{m}$ and $70 \mu \mathrm{m}$,

- cooling gas pressure: $0.6 \mathrm{MPa}$ and $0.7 \mathrm{MPa}$.

The gas was dosed by a membrane injector, shown in figure 1 , coupled to the welding head.

\section{Research methods}

After welding of $2 \mathrm{~mm}$ thick sheets of DOCOL 1200M steel using micro-jet cooling, non-destructive (NDT) and destructive tests were carried out. As part of the non-destructive testing, visual tests (VT) of welded joints were performed both with and without micro-jet cooling. The tests were performed with an eye equipped with a magnifying glass at $3 \times$ magnification (three times) according to the requirements of PN-EN ISO 17637, evaluation criteria according to EN ISO 5817. Additionally, a magnetic-particle test (MT) was carried out. The tests were carried out according to PN-EN ISO 17638, the assessment was carried out according to EN ISO 5817 using a REM-230 magnetic flaw detector. As part of destructive testing, it was decided to check the tensile strength of the welded joints tested and to analyze their microstructure. Tests for the mechanical properties of the joint were made on the ZWICK 100N5A testing machine. 


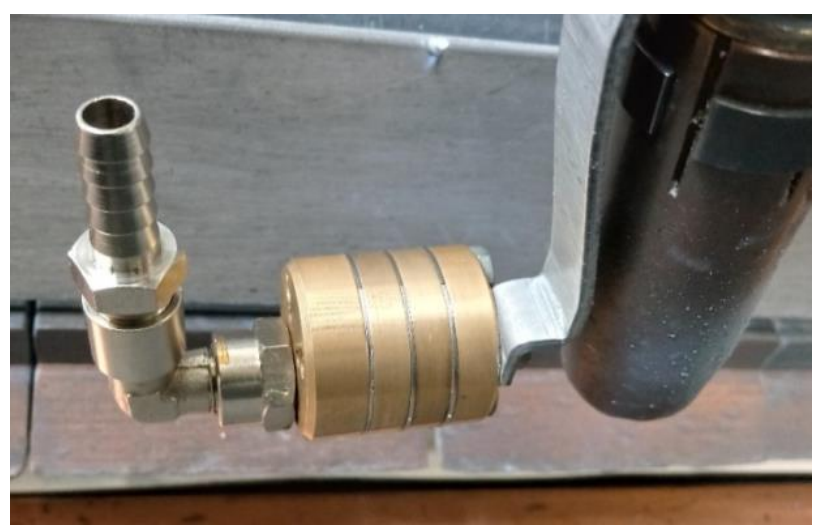

Fig. 1. Micro-jet injector with welding head

\section{Research results and their analysis}

Macroscopic and magnetic-particle tests showed that all analyzed welds were made correctly, the results of visual and magnetic-particle tests were positive. This indicates that the welding parameters selected are appropriate for welding DOCOL $1200 \mathrm{M}$ steel and allow joints to be made without surface defects such as cracks and microcracks. In order to characterize the mechanical properties of the joint, tests were carried out on the ZWICK 100N5A testing machine. The test results (average of three measurements) are given in table IV.

Table IV. NDT assessment of welded joint in movable platform

\begin{tabular}{cccccc}
\hline $\begin{array}{c}\text { Micro-jet } \\
\text { cooling }\end{array}$ & $\begin{array}{c}\text { Micro-jet } \\
\text { diameter, } \\
\boldsymbol{\mu m},\end{array}$ & $\begin{array}{c}\text { Micro-jet } \\
\text { pressure, } \\
\mathbf{M P a}\end{array}$ & $\begin{array}{c}\mathbf{R m ,} \\
\mathbf{M P a}\end{array}$ & $\begin{array}{c}\mathbf{R e}, \\
\mathbf{M P a}\end{array}$ & $\begin{array}{c}\text { A5, } \\
\mathbf{\%}\end{array}$ \\
\hline none & - & - & 758 & 452 & 6.3 \\
argon & 60 & 0.6 & 805 & 520 & 6.8 \\
helium & 60 & 0.6 & 830 & 538 & 6.9 \\
argon & 60 & 0.7 & 815 & 524 & 6.8 \\
helium & 60 & 0.7 & 835 & 541 & 7.0 \\
argon & 70 & 0.6 & 828 & 540 & 6.9 \\
helium & $\mathbf{7 0}$ & $\mathbf{0 . 6}$ & $\mathbf{8 3 8}$ & $\mathbf{5 4 4}$ & $\mathbf{7 . 1}$ \\
argon & 70 & 0.7 & 821 & 530 & 6.9 \\
helium & 70 & 0.7 & 832 & 541 & 7.0 \\
\hline
\end{tabular}

The data in table IV shows that micro-jet cooling is very beneficial. Joint strength increased from 758 to $842 \mathrm{MPa}$ using helium micro-jet cooling. The most important benefit of using micro-jet cooling is the increase in A5 relative elongation from 6.3 to max. $7.1 \%$. It was noted that helium is the more preferred gas used for micro-jet cooling. Helium cooling is more effective due to the much higher thermal conductivity of helium $(0.152 \mathrm{~W} /(\mathrm{m} \cdot \mathrm{K})$ compared to argon $(0.017 \mathrm{~W} /(\mathrm{m} \cdot \mathrm{K})$. The analysis of array data shows that the method of cooling the joint must be carefully selected. There is a limit value for increasing the intensity of micro-jet cooling, exceeding of which begins to deteriorate the mechanical properties of the welded joint. The best results were obtained using the following parameters of micro-jet cooling:

- gas: helium,

- micro-jet diameter: $70 \mu \mathrm{m}$;

- gas flow rate: $0.6 \mathrm{MPa}$.

The microstructure of the cross-section of the weld with the dominant area with martensitic structure is shown in figures 2 and 3 . The joint shown in figure 2 is dominated by the martensitic structure. Coarsegrained ferrite and bainite traces are noticeable. The presence of coarse-grained ferrite in the weld is undesirable and translates into poorer plastic properties of the joint (relative elongation is $6.5 \%$ ). Figure 3 shows martensite and fine-grained ferrite. It is a more favorable structure that allows obtaining better plastic properties (relative elongation is at the level of $7 \%$ ). It has been observed that the ferrite in the helium-cooled joint is clearly fine-grained compared to the MAG joint without micro-jet cooling. It is believed that this structure may have an impact on increasing the service life of the joint. 


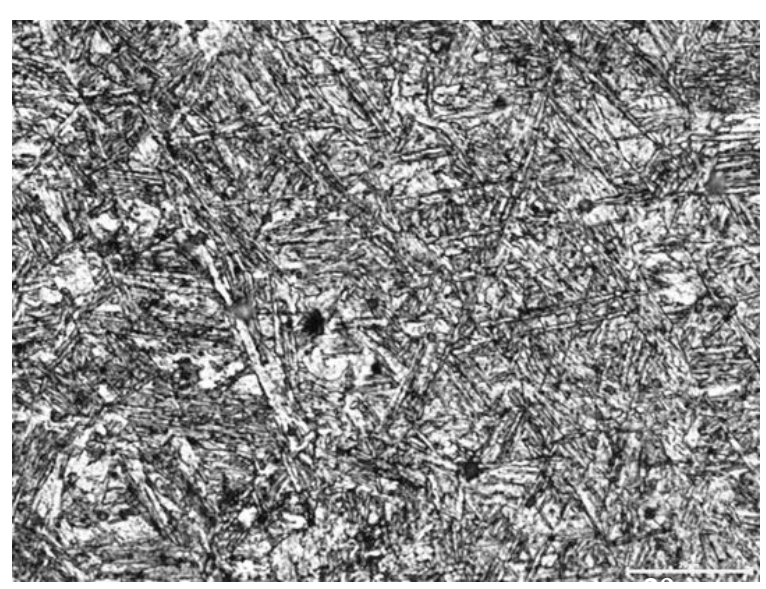

Fig. 2. Microstructure of DOCOL $1200 \mathrm{M}$ steel welded joint obtained by $\mathrm{MAG}$ with $82 \% \mathrm{Ar}+18 \% \mathrm{CO}_{2}$ without micro-jet cooling

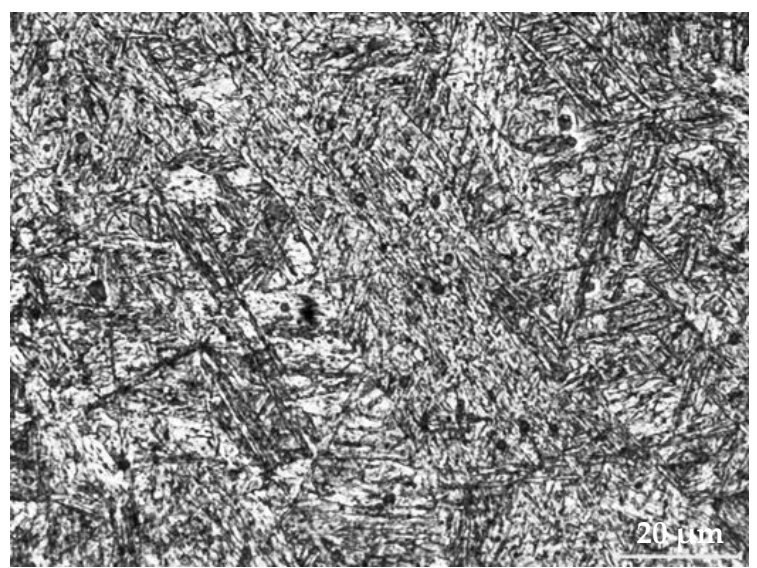

Fig. 3. Microstructure of DOCOL $1200 \mathrm{M}$ steel welded joints by MAG with $82 \% \mathrm{Ar}+18 \% \mathrm{CO}_{2}$ under helium micro-jet cooling (dimention of micro-jet: $70 \mu \mathrm{m}$; gas pressure: Micro-stream diameter 0.6 $\mathrm{MPa}$

\section{Summary}

The development of civil engineering and transport put new requirements for designers. There is a growing demand for the development of new welding processes that allow welding of new materials, often difficult to weld. Difficult to weld AHSS steel $[16,17]$ is an increasingly used material in the construction of means of transport. Its high strength is almost $35 \%$ greater than the strength of the MAG welded joint. The relative elongation of AHSS steel conventionally made with MAG or laser $[16,17]$ (without micro-jet cooling) is at a low level, as evidenced by the low plastic properties of the joints. Therefore, new solutions are sought to guarantee the improvement of weldability of thin-walled AHSS steel structures. For this purpose, the micro-jet cooling process was developed (its parameters were selected) and it was used during the welding of DOCOL $1200 \mathrm{M}$ steel by the MAG method.

As a result of the use of micro-jet cooling, higher durability of the joint was obtained in comparison to classic joints made using the MAG method. After welding with argon and helium micro-jet cooling, non-destructive testing did not reveal any welding defects and incompatibilities, which proves the possibility of using the analyzed welding process for joining the DOCOL $1200 \mathrm{M}$ steel.

As a result of the research, it was found that the most beneficial micro-jet gas used for cooling after the MAG welding process of DOCOL $1200 \mathrm{M}$ steel is helium. As a result of using helium as a micro-jet gas with a pressure of $0.6 \mathrm{MPa}$ and a diameter of micro-jet: $70 \mu \mathrm{m}$, a joint with increased tensile strength of $830 \mathrm{MPa}$ was obtained, which constitutes almost $70 \%$ of the strength of the native material. Welding of DOCOL 1200 $\mathrm{M}$ steel with the MAG method using helium micro-jet cooling allows for a noticeable increase in the relative elongation of the joint compared to the result obtained without cooling from 6.3 to $7.1 \%$.

Author Contributions: conceptualization T. W., B. S.-L.; methodology B. S.-L., A. J.; software A. S.; validation A. J., B. S.-L., T. W.; formal analysis A. S.; investigation T. W.; resources A. S.; data curation B. S.L.; writing-original draft preparation B. S.-L.; writing - review and editing T. W.; visualization B. S.-L.; supervision B. S.-L.; project administration T. W.; funding acquisition A. J. 
Funding: The paper is part of the COST project, CA 18223

Conflicts of Interest: The authors declare no conflict of interest.

\section{References}

[1] Grajcar A., Różański M., Weldability of high-strength AHSS multiphase steels (in polish), Welding Technology Review, 2014, Vol. 86(3), 22-27. https://doi.org/10.26628/ps.v86i3.103

[2] Lee C.-H., Shin H.-S., Park K.-T., Evaluation of high strength TMCP steel weld for use in cold regions, Journal of Constructional Steel Research, 2012, Vol. 74, 134-139. https://doi.org/10.1016/j.jcsr.2012.02.012

[3] Krajewski S., Nowacki J., Microstructure and properties of high strength AHSS steel, Welding Technology Review, 2011, Vol. 83(7), 1-20.

[4] Górka J., Ozgowicz W., Structure and properties of DOCOL 1200M steel spot welds, Spajanie Materiałów Konstrukcyjnych, 2019, Vol. 1(39), 26-31.

[5] Lee J., Asim K., Pan J., Modeling of failure mode of laser welds in lap-shear speciments of HSLA steel sheets, Engineering Fracture Mechanics, 2011, Vol. 78(1), 347-396. https://doi.org/10.1016/j.engfracmech.2010.10.011

[6] Celin R., Burja J., Effect of cooling rates on the weld heat affected zone coarse grain microstructure, Metallurgical and Materials Engineering, 2018, Vol. 24(1), 37-44. https://doi.org/10.30544/342

[7] Skowrońska B., Chmielewski T., Golański D., Szulc Jacek, Weldability of S700MC steel welded with the hybrid plasma+MAG method, Manufacturing Review, 2020, Vol. 7(4), 1-15. https://doi.org/10.1051/mfreview/2020001

[8] Szczucka-Lasota B., Węgrzyn T., Stanik Z., Piwnik J., Sidun P., Selected parameters of micro-jet cooling gases in hybrid spraying process, Arch. of Metallurgy and Materials, 2016, Vol. 61(2), 621-624. https://doi.org/10.1515/amm$\underline{2016-0105}$

[9] Skowrońska B., Szulc J., Chmielewski T., Sałaciński T., Swiercz R., Properties and microstructure of hybrid Plasma+MAG welded joints of thermomechanically treated S700MC steel, Proceedings of the 27th Anniversary International Conference on Metallurgy and Materials (METAL), Brno, Czech Republic, 25 May 2018.

[10] Darabi J., Ekula K., Development of a chip-integrated micro cooling device, Microelectronics Journal, Vol. 34(11), 1067-1074. https://doi.org/10.1016/j.mejo.2003.09.010

[11] Hadryś D., Impact load of welds after micro-jet cooling, Archives of Metallurgy and Materials, 2015, Vol. 60(4), 2525-2528. https://doi.org/10.1515/amm-2015-0409

[12] Muszynski T., Mikielewicz D., Structural optimization of microjet array cooling system, Applied Thermal Engineering, 2017, Vol. 123, 103-110. https://doi.org/10.1016/j.applthermaleng.2017.05.082

[13] Walsh S. M., Smith J. P., Browne E. A., Hennighausen T. W., Malouin B. A., Practical Concerns for Adoption of Microjet Cooling, Conference Proceedings, ASME 2018 International Technical Conference and Exhibition on Packaging and Integration of Electronic and Photonic Microsystems, 2018. https://doi.org/10.1115/IPACK2018-8468

[14] https://www.yumpu.com/docol-m-zimnowalcowana-stal-martenzytyczna-ssab

[15] Jaeschke B., Weglowski M., Chmielewski T., Current State and Development Opportunities of Dynamic Power Source for GMA Welding Processes, Journal of Manufacturing Technologies, 2017, Vol. 42(1), 23-30.

[16] Ahiale G. K., Oh Y.-J., Microstructure and fatigue performance of buttwelded joints in advanced high-strength steels, Materials Science \& Engineering A, 2014, Vol. 597, 342-348. https://doi.org/10.1016/j.msea.2014.01.007

[17] Sharma R. S., Molian P., Weldability of advanced high strength steels using an Yb:YAG disk laser, Journal of Materials Processing Technology, 2011, Vol. 211(11), 1888-1897. https://doi.org/10.1016/j.jmatprotec.2011.06.009

(C) 2020 by the authors. Submitted for possible open access publication under the terms and conditions of the Creative Commons Attribution (CC BY) license (http://creativecommons.org/licenses/by/4.0/). 